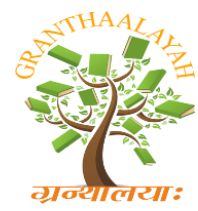

INTERNATIONAL JOURNAL OF RESEARCH GRANTHAALAYAH

A knowledge Repository

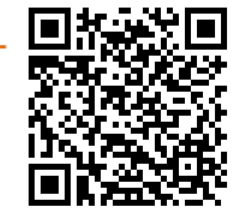

Management

\title{
PREDICTING BANKRUPTCY OF SELECTED FIRMS BY APPLYING ALTMAN'S Z-SCORE MODEL
}

\author{
Prof. Rohini Sajjan *1 \\ *1 Assistant Professor, Management Department, Indian Academy School of Management \\ Studies, Bangalore-560016, INDIA
}

\begin{abstract}
Predication of Bankruptcy is critical task. Early stage of identification of likelihood of solvency may avoid evils in the near future \& may shelter the firm from Bankruptcy situation. Bankruptcy of organizations can be predicated by using Altman's Z-Score Model. This study tries to apply the model to understand the likelihood of Bankruptcy of selected firms for past 5 years from 2011 to 2015 which are listed in BSE \& NSE. Companies are selected from manufacturing \& non-manufacturing sector. The study reveals that none of the companies completely belongs to Safe Zone except for few years. Most of the firms are in Distress Zone which clearly indicates that these firms may go Bankrupt in near future.
\end{abstract}

Keywords:

Bankruptcy; Altman's Z-Score Model.

Cite This Article: Prof. Rohini Sajjan, "PREDICTING BANKRUPTCY OF SELECTED FIRMS BY APPLYING ALTMAN'S Z-SCORE MODEL” International Journal of Research Granthaalayah, Vol. 4, No. 4 (2016): 152-158.

\section{INTRODUCTION}

Most of the organizations exist with an objective of profit maximization. To achieve profit maximization objective, firm needs strong internal \& external support. The failure of internal support system such as effective utilization of funds, labor, material etc \& external support system such as economic, political \& socio-cultural conditions results in Bankruptcy of the organization.

Bankruptcy is a situation where the firm's total liabilities exceed total assets. The real net worth of the firm is, therefore negative. This leads to reduced sales, increased cost \& losses, ineffective competition etc. Ultimately firm will be under distress stage. Under such situations it becomes difficult for investors \& lenders to analyze the financial performance of the organization. 
Several bankruptcy models for example, logit analysis, recursive portioning algorithm and neural networks are available but still Altman's model is considered to be superior and pervasively applied by researchers all over the world in the present days.

Altman's Z-Score Model is the output of a credit-strength test that predicts company's likelihood of bankruptcy.

\section{OBJECTIVES OF THE STUDY}

This study intends to estimate likelihood of Bankruptcy of selected firms by applying Altman's Z-Score Model

\section{ALTMAN'S Z-SCORE MODEL}

Edward Altman Finance Professor of the Leonard N. Stern School of Business of New York University has developed the Financial Model in 1967 to predict the likelihood of bankruptcy of the company which is named as Altman's Z-Score Model. Later, in 2012 he released an updated version called the Altman's Z-Score plus Model that can be used to evaluate both manufacturing \& non-manufacturing firms \& public \& privative companies in both U.S \& non-U.S companies. The investors can use this model to determine whether to buy or sell a particular stock if they are concerned about the financial strength of the organization. The Altman Z-score Plus can be used to evaluate corporate credit risk.

Altman added a statistical technique called multivariate analysis to the mix of traditional ratioanalysis techniques, and this allowed him to consider not only the effects of several ratios on the "predictiveness" of his bankruptcy model, but to consider how those ratios affected each other's usefulness in the model. The model formed by Altman for predicting a company's financial health is as follows;

\subsection{THE ORIGINAL Z-SCORE FORMULA OR FOR MANUFACTURING FIRMS}

$\mathrm{X} 1=$ Working Capital / Total Assets

X2 = Retained Earnings / Total Assets

X3 = Earnings Before Interest and Taxes / Total Assets

X4 = Market Value of Equity / Total Liabilities

X5 = Sales / Total Assets

\section{Z score bankruptcy model:}

$\mathrm{Z}=1.2 \mathrm{X} 1+1.4 \mathrm{X} 2+3.3 \mathrm{X} 3+0.6 \mathrm{X} 4+.999 \times 5$

\section{Zones of Discrimination:}

Z $>2.99$-"Safe" Zone

$1.81<Z<2.99$-"Gray" Zone

$\mathrm{Z}<1.81$-"Distress" Zone 


\subsection{Z-SCORE FORMULA FOR NON-MANUFACTURING FIRMS}

$\mathrm{X} 1=($ Current Assets - Current Liabilities $) /$ Total Assets

X2 = Retained Earnings / Total Assets

X3 = Earnings Before Interest and Taxes / Total Assets

X4 = Book Value of Equity / Total Liabilities

\section{Z-Score bankruptcy model:}

$\mathrm{Z}=6.56 \mathrm{X} 1+3.26 \mathrm{X} 2+6.72 \mathrm{X} 3+1.05 \mathrm{X} 4[4]$

\section{Zones of discriminations:}

$Z>2.6$-"Safe" Zone

$1.1<\mathrm{Z}<2.6$-"Grey" Zone

$\mathrm{Z}<1.1$-"Distress" Zone

\section{METHODOLOGY}

\subsection{DATA COLLECTION \& RESEARCH SAMPLE}

The study depends on the secondary source \& annual reports (financial statements) are collected from the websites of respective organizations. The time frame of data being collected is set for past 5 years i.e. from 2011 to 2015. Study covers the sample size of 6 companies which listed in Indian stock exchanges off which 3 are from manufacturing sector \& other 3 are from nonmanufacturing sector. In each sector, the companies are selected based on the high profits, high loss \& average profit/loss earned by them in each year. And it also considers the assets \& liabilities of companies while selecting the sample

And collected data is analyzed by using Excel.

Below shown are the companies which are selected for the study for the period of 5 years.

\subsection{MANUFACTURING COMPANIES}

- ACC Cement Ltd (Generated Profits in all 5 years)

- Hindustan Machine Tools Ltd (HMT) (Incurred Losses in all 5 years)

- Adani Enterprise Ltd (Generated Profits in few years \& Losses in few years)

\subsection{SERVICES COMPANIES}

- Axis bank (Generated Profits in all 5 years)

- Mahanagar Telephone Nigam Limited (MTNL) (Incurred Losses in all 5 years)

- SKS Micro Finance (Generated Profits in few years \& Losses in few years) 


\section{DATA ALALYSIS \& FINDINGS}

\subsection{MANUFACTURING COMPANIES}

ACC Cement Ltd:

\begin{tabular}{|l|l|l|l|l|l|}
\hline Particulars & $\mathbf{2 0 1 5}$ & $\mathbf{2 0 1 4}$ & $\mathbf{2 0 1 3}$ & $\mathbf{2 0 1 2}$ & $\mathbf{2 0 1 1}$ \\
\hline $\mathbf{X 1}$ & -0.03587 & -0.01191 & 0.074433 & 0.138207 & -0.00671 \\
\hline $\mathbf{X} 2$ & 0.806455 & 0.791518 & 0.781788 & 0.738638 & 1.192753 \\
\hline $\mathbf{X 3}$ & 0.189518 & 0.250383 & 0.294491 & 0.450312 & 0.771077 \\
\hline $\mathbf{X 4}$ & 0 & 0 & 0 & 0 & 0 \\
\hline $\mathbf{X 5}$ & 0.892294 & 0.92473 & 0.920491 & 0.951262 & 1.146959 \\
\hline $\mathbf{Z}$ & $\mathbf{1 . 8 5 2 3 9 8}$ & $\mathbf{1 . 9 5 4 7 1 9}$ & $\mathbf{2 . 0 7 1 2 0 3}$ & $\mathbf{2 . 2 7 8 4 1 9}$ & $\mathbf{3 . 1 0 4 0 7 4}$ \\
\hline
\end{tabular}

Hindustan Machine Tools (HMT) Ltd:

\begin{tabular}{|l|l|l|l|l|l|}
\hline Particulars & $\mathbf{2 0 1 5}$ & $\mathbf{2 0 1 4}$ & $\mathbf{2 0 1 3}$ & $\mathbf{2 0 1 2}$ & $\mathbf{2 0 1 1}$ \\
\hline X1 & -3.63141 & -2.93987 & -3.34716 & -2.56472 & -2.06386 \\
\hline $\mathbf{X} 2$ & -11.696 & -10.103 & -10.2659 & -8.57175 & -3.4474 \\
\hline $\mathbf{X 3}$ & -1.44315 & -1.5761 & -0.69532 & -0.567 & -0.29829 \\
\hline $\mathbf{X} 4$ & 0 & 0 & 0 & 0 & 0 \\
\hline $\mathbf{X 5}$ & 0.446564 & 0.423785 & 0.600446 & 0.670434 & 0.014094 \\
\hline $\mathbf{Z}$ & $\mathbf{- 1 6 . 3 2 4}$ & $\mathbf{- 1 4 . 1 9 5 2}$ & $\mathbf{- 1 3 . 7 0 7 9}$ & $\mathbf{- 1 1 . 0 3 3}$ & $\mathbf{- 5 . 7 9 5 4 6}$ \\
\hline
\end{tabular}

Adani Enterprise Ltd:

\begin{tabular}{|l|l|l|l|l|l|}
\hline Particulars & $\mathbf{2 0 1 5}$ & $\mathbf{2 0 1 4}$ & $\mathbf{2 0 1 3}$ & $\mathbf{2 0 1 2}$ & $\mathbf{2 0 1 1}$ \\
\hline X1 & -0.09308 & -0.09959 & -0.06371 & -0.04662 & 0.004293 \\
\hline X2 & 0.119686 & 0.115422 & 0.096546 & 0.083018 & 0.105249 \\
\hline X3 & 0.24078 & 0.193635 & 0.121696 & 0.126106 & 0.063122 \\
\hline X4 & 0 & 0 & $4.7 \mathrm{E}-09$ & $5.66 \mathrm{E}-09$ & $9.36 \mathrm{E}-07$ \\
\hline X5 & 0.493031 & 0.465202 & 0.414727 & 0.367531 & 0.038188 \\
\hline Z & $\mathbf{0 . 7 6 0 4 2 1}$ & $\mathbf{0 . 6 7 4 6 7 1}$ & $\mathbf{0 . 5 6 9 2 5 8}$ & $\mathbf{0 . 5 3 0 0 3 9}$ & $\mathbf{0 . 2 1 0 8 5 3}$ \\
\hline
\end{tabular}

\subsection{SERVICES COMPANIES}

Axis Bank Ltd:

\begin{tabular}{|l|l|l|l|l|l|}
\hline Particulars & $\mathbf{2 0 1 5}$ & $\mathbf{2 0 1 4}$ & $\mathbf{2 0 1 3}$ & $\mathbf{2 0 1 2}$ & $\mathbf{2 0 1 1}$ \\
\hline $\mathbf{X 1}$ & -3.84451 & -4.08709 & -4.23529 & 1.098543 & -5.46788 \\
\hline $\mathbf{X 2}$ & 0.187384 & 0.175404 & 0.149501 & 0.130204 & 0.249668 \\
\hline $\mathbf{X 3}$ & 0.162278 & 0.16488 & 0.150451 & 0.147624 & 1.856489 \\
\hline $\mathbf{X 4}$ & 0.04192 & 0.049423 & 0.055473 & 0.04217 & 0.001776 \\
\hline $\mathbf{Z}$ & $\mathbf{- 3 . 4 5 2 9 3}$ & $\mathbf{- 3 . 6 9 7 3 9}$ & $\mathbf{- 3 . 8 7 9 8 7}$ & $\mathbf{1 . 4 1 8 5 4 2}$ & $\mathbf{- 3 . 3 5 9 9 4}$ \\
\hline
\end{tabular}


Mahanagar Telephone Nigam Limited (MTNL):

\begin{tabular}{|l|l|l|l|l|l|}
\hline Particulars & $\mathbf{2 0 1 5}$ & $\mathbf{2 0 1 4}$ & $\mathbf{2 0 1 3}$ & $\mathbf{2 0 1 2}$ & $\mathbf{2 0 1 1}$ \\
\hline $\mathbf{X 1}$ & -1.93168 & -1.65366 & -1.64614 & -1.03816 & -1.51541 \\
\hline $\mathbf{X 2}$ & 0.082051 & 0.433434 & -0.50804 & 0.146239 & 0.714674 \\
\hline $\mathbf{X 3}$ & -0.4576 & -0.47844 & -1.10981 & -0.8227 & -0.67947 \\
\hline $\mathbf{X 4}$ & 0.054759 & 0.060507 & 0.046588 & 0.055719 & 0.024103 \\
\hline $\mathbf{Z}$ & $\mathbf{- 2 . 2 5 2 4 8}$ & $\mathbf{- 1 . 6 3 8 1 6}$ & $\mathbf{- 3 . 2 1 7 3 9}$ & $\mathbf{- 1 . 6 5 8 9 1}$ & $\mathbf{- 1 . 4 5 6 1}$ \\
\hline
\end{tabular}

SKS Micro Finance:

\begin{tabular}{|l|l|l|l|l|l|}
\hline Particulars & $\mathbf{2 0 1 5}$ & $\mathbf{2 0 1 4}$ & $\mathbf{2 0 1 3}$ & $\mathbf{2 0 1 2}$ & $\mathbf{2 0 1 1}$ \\
\hline $\mathbf{X 1}$ & 2.739209 & 2.319327 & 2.239516 & 2.709557 & 3.398973 \\
\hline $\mathbf{X 2}$ & -0.70373 & -1.40006 & -1.64992 & -1.84382 & 1.287141 \\
\hline $\mathbf{X 3}$ & 0.27674 & 0.187833 & -0.75214 & -5.1037 & -0.26545 \\
\hline $\mathbf{X} 4$ & 0.585215 & 0.845358 & 0.812239 & 1.130092 & 0.017553 \\
\hline $\mathbf{Z}$ & $\mathbf{2 . 8 9 7 4 3 3}$ & $\mathbf{1 . 9 5 2 4 6 2}$ & $\mathbf{0 . 6 4 9 6 9 3}$ & $\mathbf{- 3 . 1 0 7 8 7}$ & $\mathbf{4 . 4 3 8 2 1 6}$ \\
\hline
\end{tabular}

Z Value \& Firm's Classification:

\begin{tabular}{|l|l|l|l|}
\hline Company & Year & Z Value & Zone \\
\hline ACC Cement Ltd & 2015 & 1.852398 & Gray \\
\hline & 2014 & 1.954719 & Gray \\
\hline & 2013 & 2.071203 & Gray \\
\hline & 2012 & 2.278419 & Gray \\
\hline HMT & 2011 & 3.104074 & Safe \\
\hline & 2015 & -16.324 & Distress \\
\hline & 2014 & -14.1952 & Distress \\
\hline & 2013 & -13.7079 & Distress \\
\hline & 2012 & -11.033 & Distress \\
\hline Adani Enterprise Ltd & 2011 & -5.79546 & Distress \\
\hline & 2015 & 0.760421 & Distress \\
\hline & 2014 & 0.674671 & Distress \\
\hline & 2013 & 0.569258 & Distress \\
\hline & 2012 & 0.530039 & Distress \\
\hline Axis bank Ltd & 2011 & 0.210853 & Distress \\
\hline & 2015 & -3.45293 & Distress \\
\hline & 2014 & -3.69739 & Distress \\
\hline & 2013 & -3.87987 & Distress \\
\hline & 2012 & 1.418542 & Gray \\
\hline MTNL & 2011 & -3.35994 & Distress \\
\hline & 2015 & -2.25248 & Distress \\
\hline & 2014 & -1.63816 & Distress \\
\hline & 2013 & -3.21739 & Distress \\
\hline & & & \\
\hline
\end{tabular}




\begin{tabular}{|l|l|l|l|}
\hline & 2012 & -1.65891 & Distress \\
\hline & 2011 & -1.4561 & Distress \\
\hline SKS Micro Finance & 2015 & 2.897433 & Safe \\
\hline & 2014 & 1.952462 & Gray \\
\hline & 2013 & 0.649693 & Distress \\
\hline & 2012 & -3.10787 & Distress \\
\hline & 2011 & 4.438216 & Safe \\
\hline
\end{tabular}

\section{INTERPRETATION}

The above table shows that from the selected sample of 6 companies 3 companies are in Distress Zone namely HMT, Adani Enterprise \& MTNL. This means that the financial performances of these companies are pathetic \& are likely to experience Bankrupt. These firms are not eligible to borrow the funds from banks \& financial institutes \& even the investors will be not interested to invest as they doesn't have any hopes to recover especially HMT \& MTNL who's Z Values are in highly negative terms. Adani Enterprise may recover over a long period of time with effective management of financial \& other resources.

Z Value of Axis Bank also falls under Distress Zone except for the year 2012. This indicates the poor financial performance of the bank. Under this case the firm has generated good amount of profits in all the 5 years but their current liabilities are in excess to current assets which indicates banks are not in a position to meet its short term obligations. Management has to take caution so that they shouldn't lose potential investors \& can continue to survive in the market.

SKS Micro Finance shows mixed zones of $\mathrm{Z}$ Value. In the initial time frame of selected period the firm was performing badly but in later years it has showed improvements \& reached safe zone.

Among the selected sample only ACC is performing consistently which is in Gray Zone.

\section{CONCLUSION}

This study investigated the applicability of the Altman's bankruptcy model to examine the financial soundness of the firms belonging to the manufacturing $\&$ non-manufacturing firms. The study covers the 6 companies \& 5 years of time frame from 2011-2016. According to findings unfortunately, none of the companies completely belongs to Safe Zone except for few years. Most of the firms are in Distress Zone which clearly indicates that these firms may go Bankrupt in near future. It's up to top level management to design effective strategies for better control \& management of resources. This may result in win-win situation for both management $\&$ investors.

\section{REFERENCES}

[1] Diakomihalis, M. (2012). The accuracy of Altman's models in predicting hotel bankruptcy. International Journal of Accounting and Financial Reporting, 2. 
[2] Lakshan, A. M. I., \& Wijekoon, W. M. H. N. (2013). The use of Financial Ratios in Predicting Corporate Failure in Sri Lanka. GSTF Journal of Business Review (GBR), 2(4), 37-43.

[3] Niresh \& Pratheepan, (2015). The Application of Altman's Z-Score Model in Predicting Bankruptcy: Evidence from the Trading Sector in Sri Lanka. International Journal of Business and Management; Vol. 10, No. 12

[4] Carson M. J. (1995). Financial Distress in the Life Insurance Industry: An Empirical Examination. Illinois University.

[5] Altman, E. I. (1968). Financial Ratios, Discriminant Analysis and the Prediction of Corporate Bankruptcy. The Journal of Finance, 23(4), 589-609. http://dx.doi.org/10.1111/j.1540-6261.1968.tb00843.x

[6] Scott, J. (1981). The probability of bankruptcy: A comparison of empirical predictions and theoretical models. Journal of Banking \& Finance, 5, 318-344. http://dx.doi.org/10.1016/0378-4266(81)90029-7

[7] www.moneycontrol.com , www..wikipedia.com, www.yahoofiance.com, www.nseindia.com, www.bseindia.com 